\title{
STAND STRUCTURE AND PRODUGTIVITY OF THE FIREFLY RIVERINE MANGROVE HABITAT AT THREE RIVERS IN PENINSULAR MALAYSIA
}

\author{
Nur-Fatehah SR ${ }^{1,2}$, Nur-Shafikah $\mathbf{I}^{1}$, Shamsul K ${ }^{1}$, , Wan-Juliana WA ${ }^{1,2}$, Norela Sulaiman ${ }^{1}$, \\ Shahril MH$^{3} \&$ Nurul-Darsani AD $^{3}$ \\ ${ }^{1}$ Faculty of Science and Technology, Universiti Kebangsaan Malaysia, 43600 UKM Bangi, Selangor, Malaysia \\ ${ }^{2}$ Institute for Climate Change, Universiti Kebangsaan Malaysia, 43600 UKM Bangi, Selangor, Malaysia \\ ${ }^{3}$ TNB Research Sdn. Bhd., No. 1, Lorong Ayer Hitam, Kawasan Institusi Penyelidikan, 43000 Kajang, Selangor \\ *shamsulk@ukm.edu.my
}

Submitted January 2020; accepted March 2021

\begin{abstract}
Studies on floristic composition, forest structure and tree diversity are important to determine the pattern of stand structure, current status and floristic variation of firefly riverine mangrove habitats in Peninsular Malaysia. Thus, this study was conducted in three rivers, namely Sungai Chukai, Terengganu, Sungai Rembau-Linggi, Negeri Sembilan and Sungai Sepetang, Taiping, Perak. A total of 647,362 and 514 tree stands measuring $1 \mathrm{~cm}$ diameter and above were enumerated in 0.5 ha plots at the three sites, respectively. A total of 40 species were recorded in Sungai Chukai, 17 species in Sungai Rembau-Linggi and 14 species in Sungai Sepetang. The 0.5, 0.35 and 0.40 ha of each study site, respectively, were capable of capturing all the species in the mangrove forest. Rhizophoraceae family was found to have the highest density and basal area in all the study sites. The highest species density for Sungai Chukai, Sungai Rembau-Linggi and Sungai Sepetang was $R$. apiculata with a density

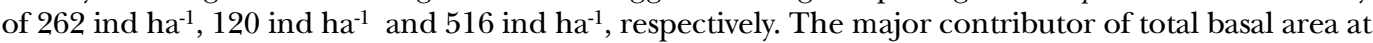
Sungai Chukai, Sungai Rembau-Linggi and Sungai Sepetang were X. granatum $\left(5.5583 \mathrm{~m}^{2} \mathrm{ha}^{-1}\right)$ and R. apiculata with $10.6833 \mathrm{~m}^{2} \mathrm{ha}^{-1}$ and $11.7491 \mathrm{~m}^{2} \mathrm{ha}^{-1}$, respectively. Diversity and species richness were higher at Sungai Chukai $\left(H^{\prime}=2.82, R^{\prime}=6.03\right)$ compared to Sungai Rembau-Linggi $\left(H^{\prime}=2.09, R^{\prime}=2.72\right)$ and Sungai Sepetang $\left(H^{\prime}=1.43, R^{\prime}=2.08\right)$. The highest total biomass of mangrove forest was at Sungai Rembau-Linggi with $321.21 \mathrm{t} \mathrm{ha}^{-1}$ followed by Sungai Sepetang (247.41 t ha-1) and Sungai Chukai $\left(210.36 \mathrm{t} \mathrm{ha}^{-1}\right)$. These results indicated that the current status of community structure and vegetation varied among the rivers. The study can act as a guideline in the management plan of firefly habitats, which also affect firefly distribution along the three rivers in Peninsular Malaysia.
\end{abstract}

Keywords: Forest structure, floristic composition, tree diversity, biomass

\section{INTRODUCTION}

The mangrove environment has some special physicochemical characteristics of salinity, tidal currents, winds, high temperatures and muddy anaerobic soil. They are not only influenced by the chemical and physical conditions of their environment, but usually help to create those conditions by themselves (Kathiresan, 2004). Mangroves occupy $18,100,000$ ha worldwide (Spalding et al. 1997), but this estimate of global coverage was revised to $13,776,000$ ha by Giri et al. (2011), and then to 8,349,500 ha by Hamilton and Casey (2016).

In 1980, the total mangrove area in Southeast Asia totals 6.8 million ha, which is about $34-42 \%$ of the world's total mangrove (Giesen et al. 2007, Wan Norilani et al. 2018). However, the area had dropped to less than 5.7 million ha in year 1990, showing a decrease in about $15 \%$ or more, than 110,000 ha per year. As the total area had also decreased to 79,000 ha between 1990-2000, there was a $13.8 \%$ decline in mangrove area during this decade. Indonesia is the country with the largest area of mangrove in Southeast Asia (almost $60 \%$ of Southeast Asia's total), while Malaysia ranking second (11.7\%), followed by Myanmar (8.8\%), Papua New Guinea $(8.7 \%)$ and Thailand (5.0\%) (Giesen et al. 2007, Jusoff 2013).

In Malaysia, the mangrove forest covers an area ofabout $627,567 \mathrm{ha}$, mostly found in Sabah, that account for $60 \%(378,195 \mathrm{ha})$, followed by Sarawak (22\% or 139,890 ha) and Peninsular Malaysia with 109,482 ha (18\%) (Hamdan Omar et al. 2018). Riverine mangrove forests 
are luxuriant patches of mangroves existing along the rivers and creeks, which experience flooding daily by the tides. Such forests are influenced with the incursion of large amount of freshwater with fluvial nutrients, and thus making the ecosystem highly productive with trees growing taller (Kathiresan 2004).

The main current issues and threats to the mangrove habitat loss in Malaysia are attributed to land conversion for agriculture, aquaculture and urban development, other than being affected by severe erosion, aggravated by anthropogenic disturbances along with the rising sea level (Awang et al. 2014, Richards \& Friess 2016, Aldrie 2018). The combined effect from these disturbances jeopardises the role of mangroves as a functional habitat that provides vital ecosystem services and connectivity, and secures the livelihoods of Malaysia's coastal communities (Chong 2006). The remaining mangroves are now fragmented and are susceptible to further disturbances, putting the ecosystems at a greater risk of collapsing (Duke et al. 2007). They may also result in the loss of a huge number of individual mangrove species ( Aldrie \& Latiff 2006).

In Malaysia, human activities have continued to threaten the habitats of the firefly, Pteroptyx tener, despite the potential economic benefits for the local people from firefly ecotourism, for example in Kuala Selangor, Kuala Sepetang and Rembau-Linggi (Jusoh et al. 2010a, 2010b, Nada et al. 2012). The general perception is that firefly populations in these areas have declined over the years due to habitat destruction and degradation as a result of anthropogenic activities, and also land use changes taking place in the area (Ohba \& Wong 2004, Jusoh et al. 2012).

The composition of plant species in the buffer zone of mangrove forest needs to be studied in order to support the effort of conservation of firefly habitats in Malaysia (Wan Juliana et al. 2012). The main objectives of this study are to determine the species composition and forest stand structure of the riverine mangrove vegetation of habitat firefly along the bank of Sungai Chukai, Sungai Sepetang and Sungai Rembau-Linggi. Data gathered may perhaps assist the management of mangrove habitat areas for both the mangrove forest and fireflies conservation.

\section{MATERIALS AND METHODS}

\section{Study site}

The study was conducted at Sungai Sepetang, Taiping, Perak $\left(4^{\circ} 50^{\prime} \mathrm{N}, 100^{\circ} 37^{\prime} \mathrm{E}\right)$, Sungai Chukai, Kemaman, Terengganu $\left(04^{\circ} 14^{\prime} \mathrm{N}\right.$, $\left.103^{\circ} 26^{\prime} \mathrm{E}\right)$ and Sungai Rembau-Linggi, Negeri Sembilan $\left(02^{\circ} 24^{\prime} \mathrm{N}, 102^{\circ} 00^{\prime} \mathrm{E}\right)$ (Figure 1). Sungai Sepetang was disturbed by human activities such as logging for wood charcoal, oil palm plantations and aquaculture, while in Sungai Chukai, the river was straightened as a canal to prevent major flood, and in Sungai Rembau-Linggi, oil palm plantations reached up to the banks.

\section{Sampling techniques}

The study was conducted at 10 locations along the riverbanks of Sungai Chukai, Sungai Sepetang and Sungai Rembau-Linggi from downstream to upstream (Figure 2). Ten plots of $25 \mathrm{~m} \times 20 \mathrm{~m}$ were established adjacent to the river at $3 \mathrm{~km}$ distance between each plots. All mangrove trees with diameter at breast height $(\mathrm{DBH}) 1 \mathrm{~cm}$ were measured and identified and curation procedure was used according to Bridson and Forman (1992). All scientific names follow the Tree Flora of Malaya, Mangrove Flora of Langkawi and The Global Biodiversity Information Facility (GBIF) (Whitmore 1972, 1973, Ng 1978, 1989, Wan Juliana et al. 2010, GBIF 2020).

\section{Data analyses}

Parameters such as frequency, density, basal area, importance value for each mangrove tree species were investigated acording to Brower et al. (1998), and DBH size class distribution were calculated and analysed for comparison (Table 1). The species diversity and richness of the forest were calculated using Shannon Wiener diversity index (Spellerberg \& Fedor 2003). To estimate the aboveground biomass (AGB), coefficients of allometric equations of Komiyama et al. (2005) were used as follows:

$$
\mathrm{W}_{\text {top }}=0.251(\rho) \mathrm{DBH}^{2.46}
$$

The chi square test for association was conducted using Minitab software version 19 to see whether 


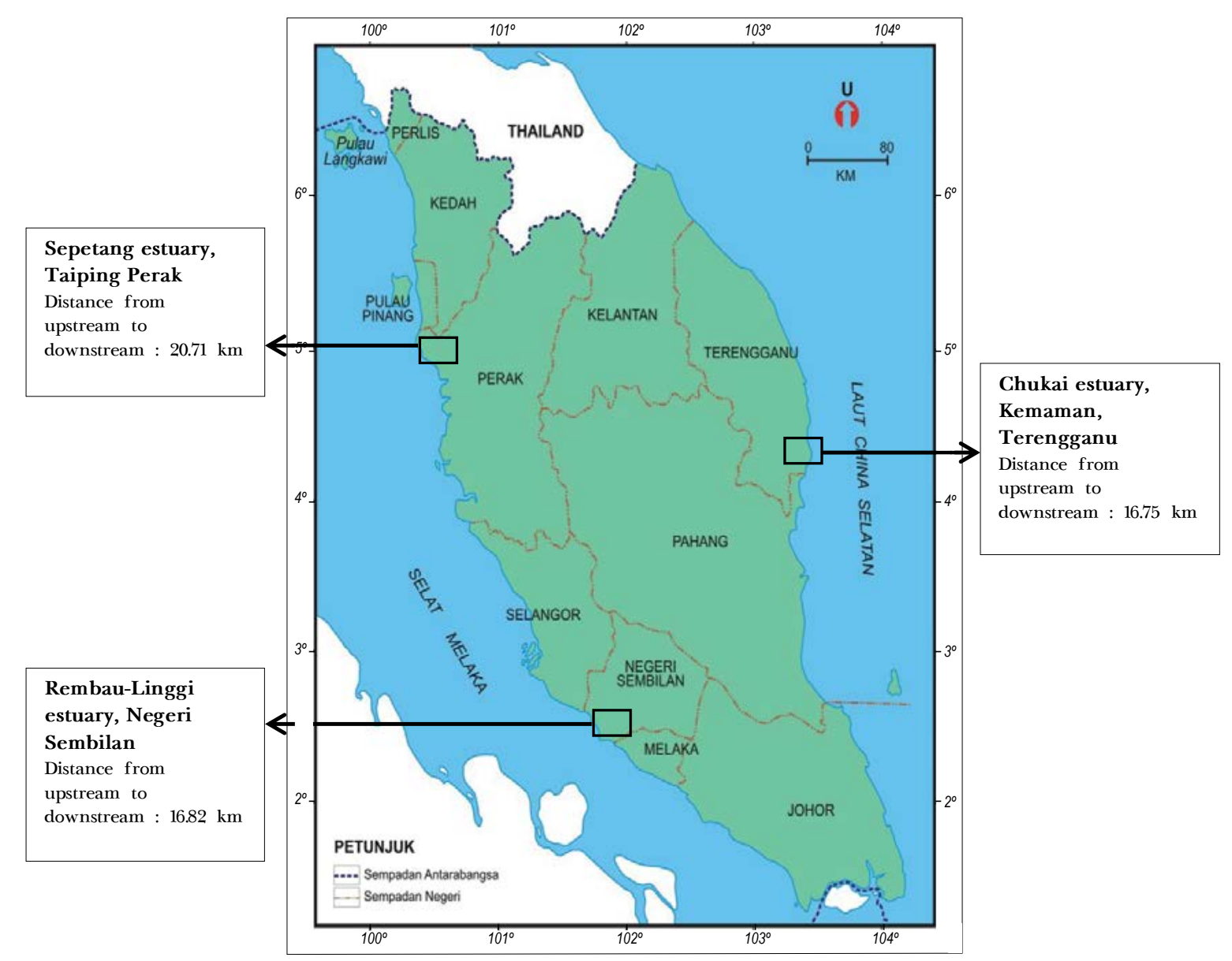

Figure 1 Map of riverine mangrove as habitat of fireflies at three selected areas (Sungai Chukai, Sungai Rembau-Linggi and Sungai Sepetang) in Peninsular Malaysia

a) Sungai Rembau-Linggi, Negeri Sembilan

b) Sungai Chukai, Kemaman, Terengganu

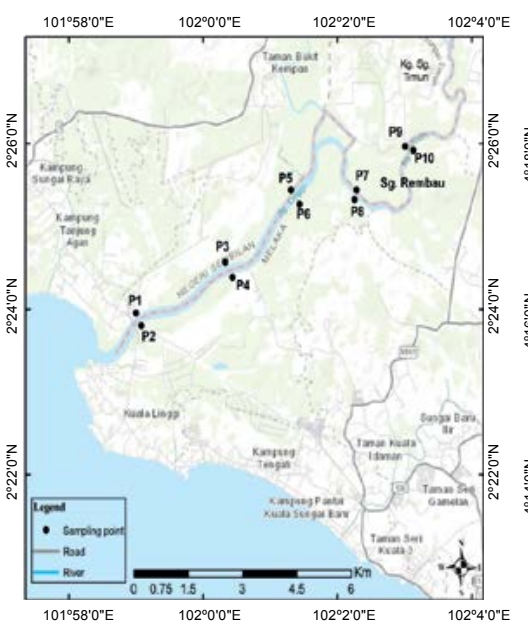

$103^{\circ} 24^{\prime} 0^{\prime \prime E}$

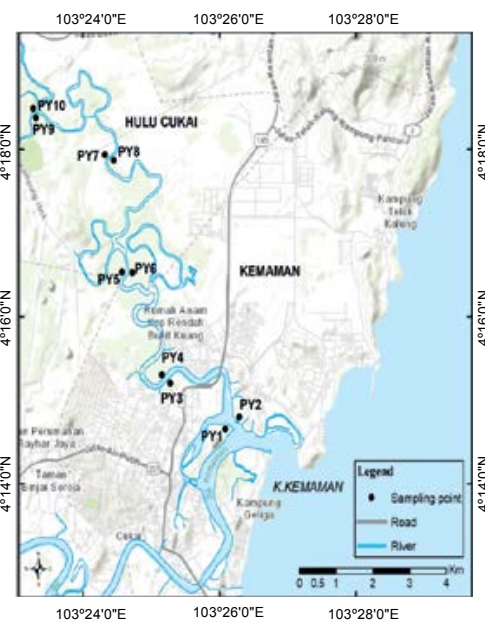

c) Sungai Sepetang, Taiping, Perak

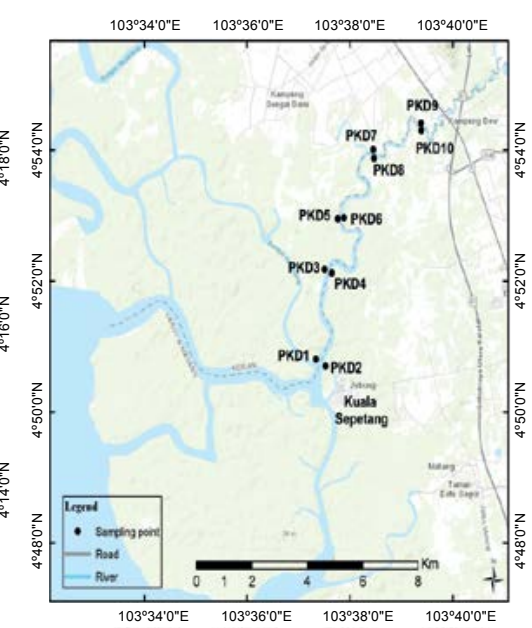

Figure 2 Sampling points along the Sungai Rembau-Linggi, Sungai Chukai and Sungai Sepetang 
Table $1 \quad(\mathrm{a}-\mathrm{c})$ : Coordinates of sampling station and description of plot area in Sungai Rembau-Linggi, Negeri Sembilan

a) Sungai Rembau-Linggi, Negeri Sembilan

\begin{tabular}{lcccl}
\hline $\begin{array}{l}\text { Sampling } \\
\text { points }\end{array}$ & $\begin{array}{c}\text { Elevation } \\
(\text { meter })\end{array}$ & $\begin{array}{c}\text { Latitude }(\mathrm{N}) \\
\left({ }^{\circ}\right)\end{array}$ & $\begin{array}{c}\text { Longitude }(\mathrm{E}) \\
\left({ }^{\circ}\right)\end{array}$ & Description \\
\hline P1 & 6.1492 & 2.3991 & 101.9833 & Muddy and brackish zone \\
P2 & 8.7979 & 2.3966 & 101.9847 & Muddy and brackish zone \\
P3 & 1.9459 & 2.4094 & 102.0056 & Intermediate estuarine zone \\
P4 & 18.4773 & 2.4063 & 102.0073 & Mangrove area near the barren land \\
P5 & 10.3514 & 2.4239 & 102.0218 & Nearby with small stream \\
P6 & 10.5813 & 2.4211 & 102.0238 & Area surrounded with oil palm plantation \\
P7 & 10.5857 & 2.4239 & 102.0380 & Area surrounded with oil palm plantation \\
P8 & 11.6418 & 2.4220 & 102.0375 & Area surrounded with oil palm plantation \\
P9 & 6.7237 & 2.4327 & 102.0501 & Forest consists of mangrove plant \\
P10 & 3.1236 & 2.4319 & 102.0521 & Forest consists of mangrove plant \\
\hline
\end{tabular}

b) Sungai Chukai, Kemaman, Terengganu

\begin{tabular}{lcccl}
\hline $\begin{array}{l}\text { Sampling } \\
\text { points }\end{array}$ & $\begin{array}{c}\text { Elevation } \\
(\text { meter })\end{array}$ & $\begin{array}{c}\text { Latitude }(\mathrm{N}) \\
\left({ }^{\circ}\right)\end{array}$ & $\begin{array}{c}\text { Longitude }(\mathrm{E}) \\
\left({ }^{\circ}\right)\end{array}$ & Description \\
\hline PY1 & 7.0216 & 4.2443 & 103.4348 & Area disjunctly along the island's coastline \\
PY2 & 7.1328 & 4.2466 & 103.4382 & Muddy and brackish zone \\
PY3 & 2.4656 & 4.2534 & 103.4213 & Area nearby with settlement \\
PY4 & 1.4549 & 4.2550 & 103.4193 & Low lying land and nearby with small stream \\
PY5 & 9.7197 & 4.2755 & 103.4095 & Forest consists of mangrove plant \\
PY6 & 9.6446 & 4.2754 & 103.4121 & Intermediate estuarine zone \\
PY7 & 2.5717 & 4.2989 & 103.4054 & Intermediate estuarine zone \\
PY8 & 7.2396 & 4.2978 & 103.4075 & Mangrove area near the barren land \\
PY9 & 2.1943 & 4.3063 & 103.3885 & Area lowland and straightened river \\
PY10 & 2.1886 & 4.3081 & 103.3879 & Near the swampy area \\
\hline
\end{tabular}

c) Sungai Sepetang, Taiping, Perak

\begin{tabular}{lcccl}
\hline $\begin{array}{l}\text { Sampling } \\
\text { points }\end{array}$ & $\begin{array}{c}\text { Elevation } \\
(\text { meter })\end{array}$ & $\begin{array}{c}\text { Latitude }(\mathrm{N}) \\
\left({ }^{\circ}\right)\end{array}$ & $\begin{array}{c}\text { Longitude }(\mathrm{E}) \\
\left({ }^{\circ}\right)\end{array}$ & Description \\
\hline PKD1 & 2.0644 & 4.8467 & 100.6223 & Area brackish zone \\
PKD2 & 2.0113 & 4.8449 & 100.6254 & Muddy and brackish zone \\
PKD3 & 2.1544 & 4.8696 & 100.6251 & Intermediate estuarine zone \\
PKD4 & 3.1215 & 4.8687 & 100.6275 & Area nearby the shrimp pond \\
PKD5 & 7.1252 & 4.8824 & 100.6295 & Mangrove area near the shrimp pond \\
PKD6 & 1.2662 & 4.8827 & 100.6315 & Low lying land and near with aquaculture \\
PKD7 & 3.6217 & 4.9002 & 100.6409 & Area surrounded with oil palm plantation \\
PKD8 & 3.1244 & 4.8979 & 100.6412 & Intermediate estuarine zone \\
PKD9 & 2.1455 & 4.9069 & 100.6564 & Nearby with small stream \\
PKD10 & 2.4265 & 4.9049 & 100.6566 & Area surrounded with oil palm plantation \\
\hline
\end{tabular}


proportion of DBH class distribution differs from each other. Rarefaction was made using $\mathrm{R}$ software version 3.6.1 to compare the richness of different sites. Statistical analysis using T-test was conducted by using PAST software version $2.17 \mathrm{c}$ based on the number of species recorded (Hammer 2012).

\section{RESULTS AND DISGUSSION}

\section{Species composition}

A total of 647 individual trees was recorded in Sungai Chukai, with 40 species and 31 genera from 20 families. In Sungai Sepetang, there were 514 individual trees recorded belonging to 14 species, 9 genera and 8 families. A total of 362 individual trees from 17 species, 12 genera and 10 families was identified at Sungai Rembau-Linggi (Table 2). The largest family in all the study sites was Rhizophoraceae, represented by 8 species in Sungai Chukai, 5 species in Sungai Sepetang, and 4 species in Sungai Rembau-Linggi (Table 3).

\section{Tree stand density}

The highest density recorded was at Sungai Chukai with 1294 ind $\mathrm{ha}^{-1}$, followed by 1028 ind $\mathrm{ha}^{-1}$ at Sungai Rembau-Linggi. The lowest density was recorded in Sungai Sepetang with 724 ind ha $^{-1}$. In all study areas it showed that $R$. apiculata had the highest total density with 240 ind ha-1 (Sungai Rembau-Linggi), 516 ind ha $^{-1}$ (Sungai Sepetang) and 262 ind ha $^{-1}$ recorded at Sungai Chukai (Table 4). A study conducted by Wan Norilani et al. (2018) showed that $R$. apiculata had the highest density at compartment 7 in Kisap Forest Reserve, Pulau Langkawi, which is similar into this study.

\section{Basal area}

The highest total basal area of mangrove stand was recorded at Sungai Rembau-Linggi with $22.35 \mathrm{~m}^{2} \mathrm{ha}^{-1}$, whereby there were many trees (16 individuals) with $\mathrm{DBH}>40 \mathrm{~cm}$ compared to Sungai Sepetang (12 individuals) and Sungai Chukai (1 individual). Meanwhile, the total basal area at Sungai Sepetang was recorded as $18.83 \mathrm{~m}^{2} \mathrm{ha}^{-1}$. The lowest total basal area was recorded at Sungai Chukai $\left(19.93 \mathrm{~m}^{2} \mathrm{ha}^{-}\right.$ $\left.{ }^{1}\right)$ because most of the individual trees in this site $(88.25 \%)$ were below $20 \mathrm{~cm}$ DBH. Rhizophoraceae was the main contributor to the total basal area at Sungai Rembau-Linggi, Sungai Sepetang and Sungai Chukai with 12.54 $\mathrm{m}^{2} \mathrm{ha}^{-1}$ (56.11\%), $13.20 \mathrm{~m}^{2} \mathrm{ha}^{-1}(70.10 \%)$ and $7.28 \mathrm{~m}^{2} \mathrm{ha}^{-1}(40.60 \%)$, respectively.

\section{Importance value index (IVi)}

The Importance Value Index of each species (SIVi) indicates species dominance. Based on SIVi, most of the study plots in the west coast of Peninsular Malaysia at Sungai Sepetang were dominated by $R$. apiculata (42.52\%), followed by Sonneratia caseolaris (21.01\%), while Sungai Rembau-Linggi were dominated by $R$. apiculata $(32.56 \%)$, followed by Xylocarpus granatum $(10.69 \%)$. However, the most important species in the east coast of Peninsular Malaysia at Sungai Chukai was $X$. granatum (16.60\%) followed by $R$. apiculata $(14.00 \%)$ (Table 4). Based on the family importance value index (FIVi), all the three study plots were dominated by Rhizophoraceae with $45.39 \%$ (Sungai Rembau-Linggi), 59.73\% (Sepetang River) and 37.92\% (Sungai Chukai). The results from this study confirmed that Rhizophoraceae was distributed all over Peninsular Malaysia with $R$. apiculata dominating almost all areas (Wan Juliana et al. 2014).

Table 2: Taxonomic composition recorded at the three study sites

\begin{tabular}{lcccc}
\hline Study sites & Family & Genera & Species & $\begin{array}{c}\text { Number of } \\
\text { individuals }\end{array}$ \\
\hline Sungai Chukai, Kemaman, Terengganu & 20 & 31 & 40 & 647 \\
Sungai Rembau-Linggi, Neger Sembilan & 10 & 12 & 17 & 362 \\
Sungai Sepetang, Taiping, Perak & 8 & 9 & 14 & 514 \\
\hline Total & 20 & 33 & 46 & 1523 \\
\hline
\end{tabular}


Table 3 The largest family was recorded at three study sites.

\begin{tabular}{llc}
\hline \multicolumn{1}{c}{ Study Sites } & \multicolumn{1}{c}{ Family } & Species \\
\hline Sungai Chukai, Kemaman, Terengganu & Rhizophoraceae & 8 \\
Sungai Sepetang, Taiping, Perak & Rhizophoraceae & 5 \\
Sungai Rembau-Linggi, Neger Sembilan & Rhizophoraceae & 4 \\
\hline
\end{tabular}

\section{Diverisity, richness and evenness for species composition}

The Shannon diversity index (H') showed that Sungai Chukai has a higher value, $\mathrm{H}^{\prime}=$ $2.82\left(\mathrm{H}^{\prime}\right.$ maks $\left.=3.69\right)$, followed by Sungai Rembau-Linggi, H' = 2.09 ( $\mathrm{H}^{\prime}$ maks = 2.83) and Sungai Sepetang $\mathrm{H}^{\prime}=1.43\left(\mathrm{H}^{\prime}\right.$ maks $=$ 2.64). Mangroves at firefly habitat in Kuala Selangor was reported to have a lower $\mathrm{H}^{\prime}$ value that ranged from 0.55 to 0.91 , compared to this study (Hemati et al. 2014). Based on the current results, there was a significant difference of species diversity between the study sites. Statistical analysis using T-test (PAST version $2.17 \mathrm{c}$ ) showed a significant difference $(p<0.05)$ between the number of individuals in all study sites. The highest species richness index $(\mathrm{R}=6.03)$ and species evenness index $(\mathrm{E}=0.76)$ were recorded in Sungai Chukai. The lowest species richness index $(\mathrm{R}=2.08)$ and species evenness index $(\mathrm{E}=0.54)$ were recorded in Sungai Sepetang (Table 5).

\section{Degree of similarity based on number of species composition}

Further cluster analysis by using PAST software version 2.17c (Hammer 2012) revealed the similarity between the study areas. Figure 3 shows relatively higher percentage of species similarity in Sungai Chukai (CE) and Sungai Rembau-Linggi (RLE), $35.1 \%$, as both of them consist of higher number of species, 40 species $\left(\mathrm{H}^{\prime}=2.82\right)$ and 17 species $\left(\mathrm{H}^{\prime}=2.09\right)$, respectively. The second clade was the Sungai Sepetang with the lowest value of similarity $(24.7 \%)$. The low percentage of similarity indicates the distance, i.e. Sungai Sepetang is located in the north east coast of Peninsular Malaysia while Sungai Rembau-Linggi is located in the south and Sungai Chukai is located in the east coast of Peninsular Malaysia. There were huge differences of species composition between the sites as indicated by low percentage of similarity. The results proved that the differences in location contributed
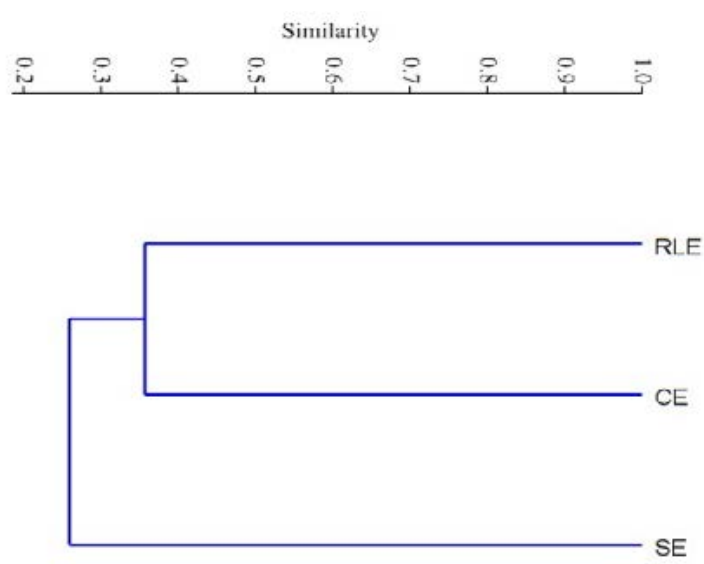

Figure 3 Dendrogram of the similarity of tree species composition at three rivers, Sungai Rembau Linggi (RLE), Sungai Sepetang (SE) and Sungai Chukai (CE), Peninsular Malaysia 


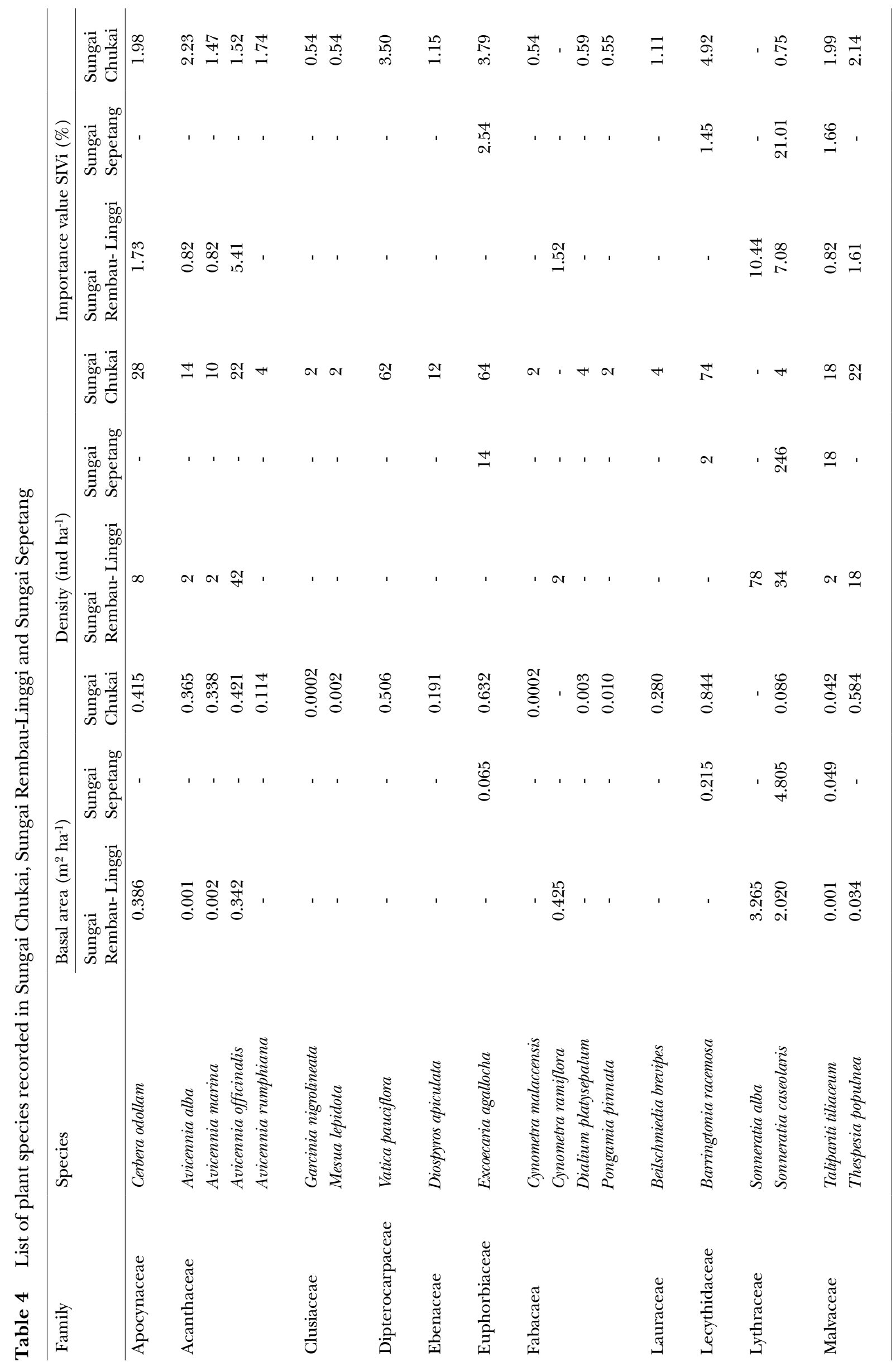




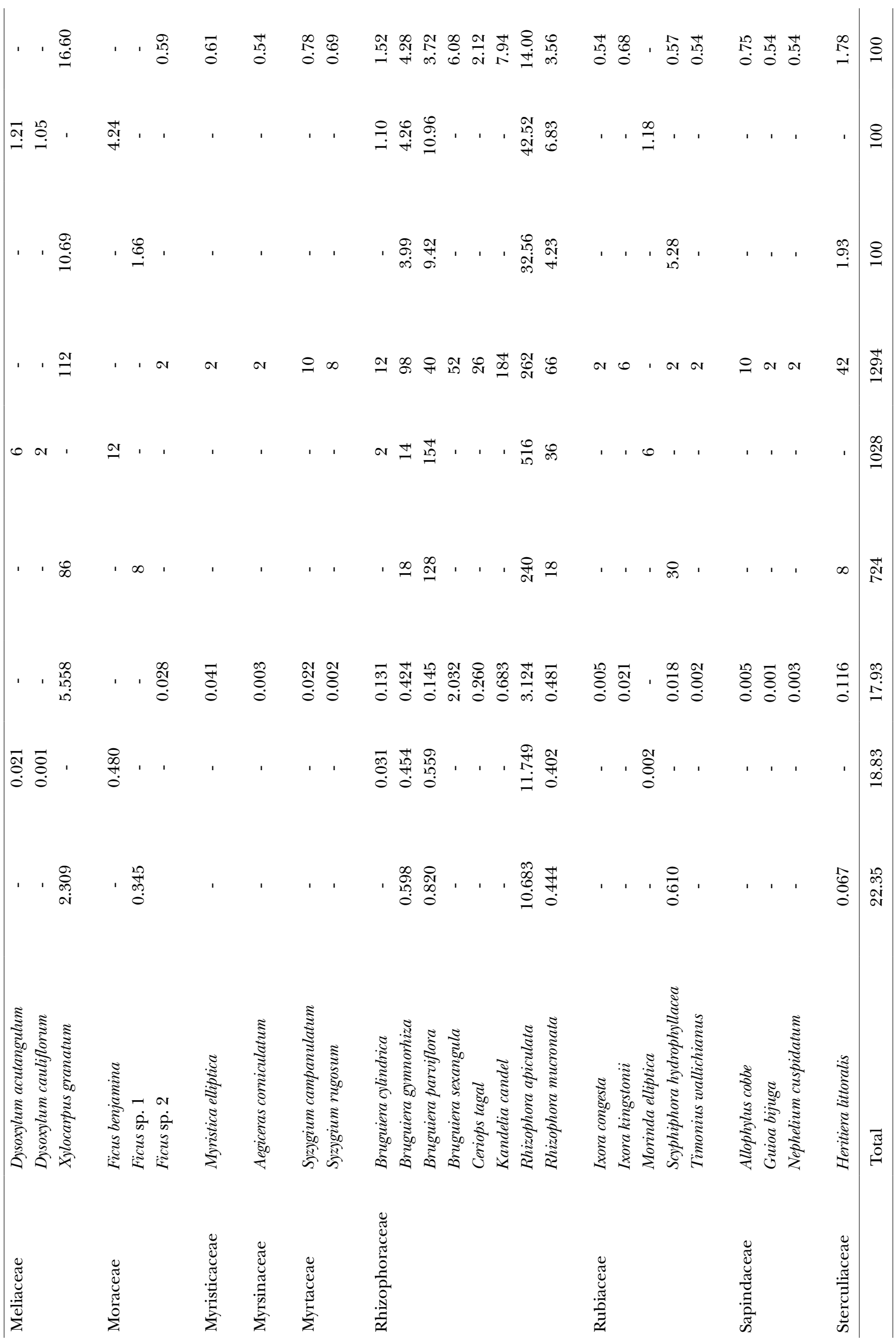


Table 5 List of diversity, evenness and richness index at three selected areas of firefly habitat in Peninsular Malaysia

\begin{tabular}{lcccc}
\hline Study site & $\begin{array}{c}\text { Area plot } \\
(\mathrm{ha})\end{array}$ & $\begin{array}{c}\text { Diversity index } \\
(\mathrm{H})\end{array}$ & $\begin{array}{c}\text { Evenness } \\
\text { index (E) }\end{array}$ & $\begin{array}{c}\text { Richness } \\
\text { index (R) }\end{array}$ \\
\hline Sungai Chukai, Kemaman, Terengganu & 0.5 & $2.82^{\mathrm{a}}$ & 0.76 & 6.03 \\
Sungai Sepetang, Taiping, Perak & 0.5 & $1.43^{\mathrm{b}}$ & 0.54 & 2.08 \\
Sungai Rembau-Linggi, Neger Sembilan & 0.5 & $2.09^{\mathrm{c}}$ & 0.74 & 2.72 \\
\hline
\end{tabular}

Means with different letters indicate significant difference by t-test $\mathrm{p}<0.05$

to mangrove plant species composition. In conclusion, there were differences in species distribution among the three sites in Peninsular Malaysia.

\section{Species accumulation curves}

The species accumulation curves were constructed to observe the trend in species accumulation for different tree size class type within the overall study site at each river (Figure 4). The asymptote for species accumulation curve in this study has yet to be reached and continued to rise upward indicating high species richness compared to the tree species in Sungai Chukai (Figure 4). However, at the $7^{\text {th }}$ plot (0.35 ha) at Sungai Sepetang, the graph started to level off because there was no increase in the number of species as the area of study increased. Meanwhile, at the $8^{\text {th }}$ plot
(0.40 ha) at Sungai Rembau-Linggi, the species accumulation curve started to approach an asymptote. The sampling is said to be adequate to capture most of the species present when a species accumulation curve approaches an asymptote; the asymptotic value is a measure of the total species complement (FaridahHanum et al. 2012). It is thus assumed that 0.5, 0.35 and 0.40 ha were capable of capturing all the species in the mangrove forest at Sungai Chukai, Sungai Sepetang and Sungai RembauLinggi, respectively.

\section{Rarefaction}

Based on this study, the sample size obtained is not the same in each plot due to the different flora and forest topography coverage in each habitat. Therefore, ecologists have adopted standardisation methods known as rarefaction

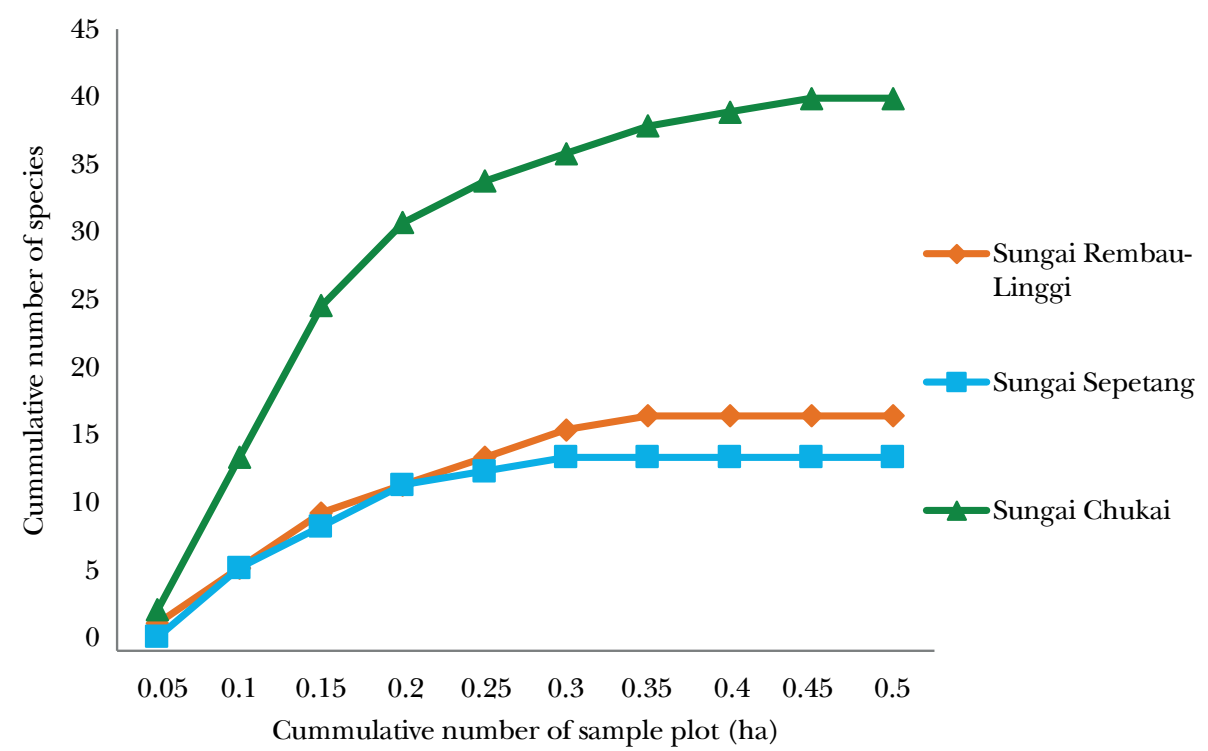

Figure 4 Species accumulation curve of a mangrove forest at three selected areas of firefly habitats in Peninsular Malaysia 
when comparing the richness of different sites or time periods (Gotelli \& Colwell 2001, Chao \& Jost 2012). Rarefaction analysis (Figure 5) was tested using $\mathrm{R}$ software version 3.6.1 aimed at making a direct comparison of species richness among the forest tree communities, based on the lowest total number of individuals in each plot (Magurran 2004). The results of the rarefaction analysis conducted showed that the Sungai Chukai has the highest species richness (40 species), followed by Sungai Rembau-Linggi (17 species) and Sungai Sepetang (14 species). This rarefaction curve explains that a large number of individuals do not reflect that the habitat is accommodating high species richness. This can be proven through the rarefaction curve which was limited to the total number of individuals (362 individuals), showing that Sungai Rembau-Linggi has a higher species richness than Sungai Sepetang. The difference in richness of tree species after rarefaction was in line with the observations on species-area curve (Figure 4), where Sungai Chukai is superior to other study areas. This is because Sungai Chukai accommodates the highest number of individual trees, families and genus compared to Sungai RembauLinggi and Sungai Sepetang (Figure 5).

\section{Forest stand structure}

Figure 6 shows the distribution of diameter class that follows the Reverse J-curve pattern in which $92.58 \%$ was represented by trees less than $30 \mathrm{~cm} \mathrm{DBH}$ from the total number of

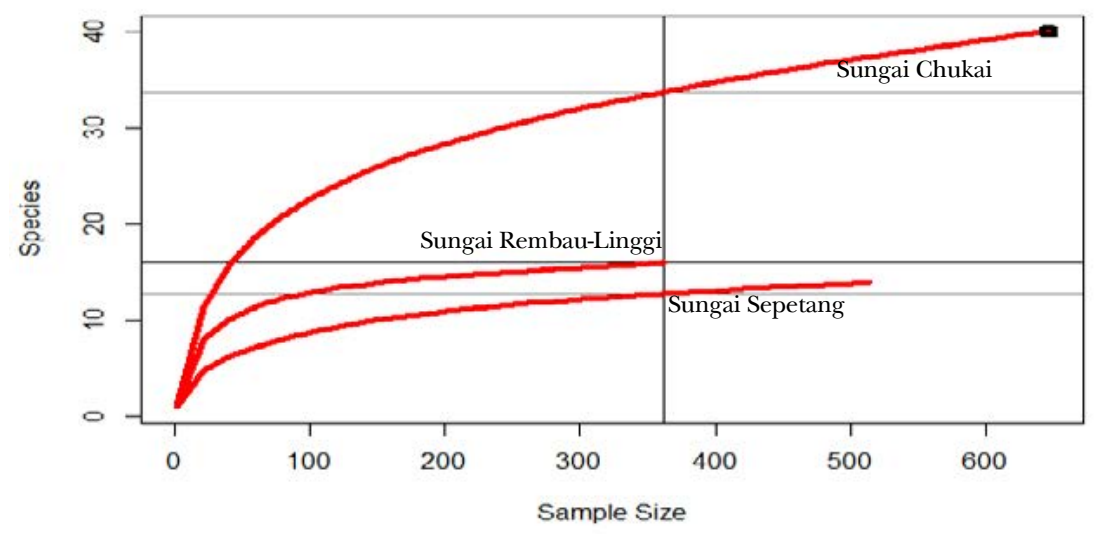

Figure 5 Rarefaction curve based on increasing number of individuals at the three rivers

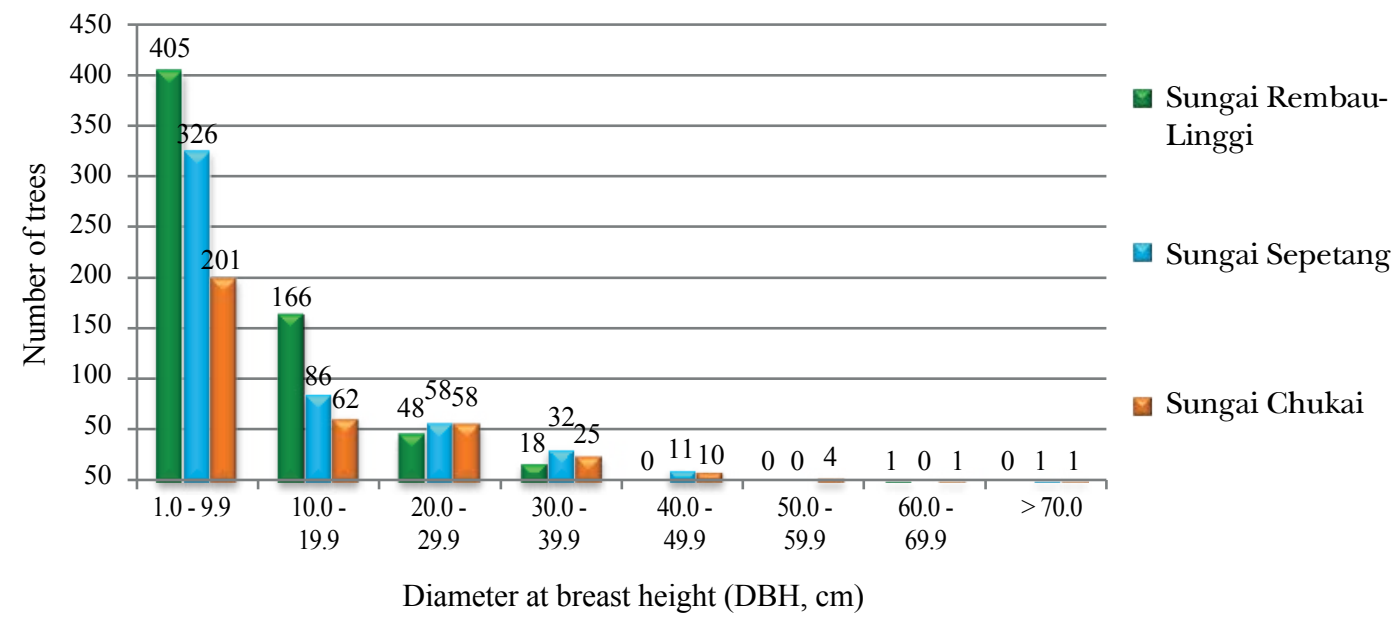

Figure 6 The diameter at breast height (DBH) class distribution of trees at three rivers in Peninsular Malaysia 
trees (1523 individuals) found in 1.5 ha, and the remaining $7.42 \%$ was from the DBH class greater than $30 \mathrm{~cm}$. The number of larger trees decreased with larger diameter class. This situation happens due to the increasing growth rate of seedlings and juvenile trees compared to mature trees (Hitimana et al. 2004). However, according to Denslow (1995) this model can be modified by some environmental factors such as differences in topography or soils, competition for resources between species or between mother trees and seedlings, tree cutting, regeneration patterns, and irregular or seasonal climatic events. Hence, DBH class distribution is often used to detect trends in regeneration patterns and to assess the disturbance effect within forests (Denslow 1995, Poorter et al. 1996). The chi square test for association (Minitab 19) was used to determine the proportion of $\mathrm{DBH}$ class distribution in three rivers. The chi square statistic value 50.997 and the result showed that there was significant difference since $(\mathrm{p}<0.05)$ of the proportion of the DBH class distribution between them.

\section{Biomass estimation}

The highest total estimation of AGB was recorded at Sungai Rembau-Linggi with $219.5 \mathrm{t} \mathrm{ha}^{-1}$, while the second highest biomass was at Sungai Sepetang (173.2 t ha-1), followed by Sungai Chukai (123.6 t ha-1), although Sungai Chukai had a higher number of individuals compared to the other study sites. The lowest value of AGB at Sungai Chukai was expected as the project of straightening the river for flood mitigation was conducted as a result of the worst floods in 2013 (MPK 2019). The estimation of the total AGB for mangrove trees at Sungai Sepetang was much lower than the Matang mangrove, as reported by Putz and Chan (1986) with the estimation value of 409 t ha ${ }^{-1}$. However, estimation of AGB at Sungai Rembau-Linggi was higher than the biomass estimation at Sungai Mengala, Port Dickson, with a value of $208.2 \mathrm{t} \mathrm{ha}^{-1}$ (Gan 2006). All the study sites showed that $R$. apiculata had the highest AGB except at Sungai Chukai. The $R$. apiculata dominated Sungai RembauLinggi and Sungai Sepetang with a total AGB of $138.07 \mathrm{t} \mathrm{ha}^{-1}(62.92 \%)$ and $136.80 \mathrm{t} \mathrm{ha}^{-1}$ $(79.00 \%)$, respectively. According to Polidoro et al. (2010) the species of Rhizophora are easily dispersed, and grow or reproduce rapidly, and cope better than the slower growing Bruguiera spp., Ceriops spp. or Xylocarpus spp. However, at Sungai Chukai, the highest total estimation of AGB was dominated by $X$. granatum with $50.03 \mathrm{t} \mathrm{ha}^{-1}$ (40.49\%), followed by R. Apiculata, $28.54 \mathrm{t} \mathrm{ha}^{-1}(23.10 \%)$ (Table 6).

\section{CONGLUSION}

The study recorded plant species composition at firefly habitats which would help in managing the habitat for the purpose of conservation and ecotourism. The community structure analysis showed that the mangrove forest of firefly habitat at Sungai Sepetang can be categorised as Rhizophora-Sonneratia since most of the study plots were dominated by $R$. apiculata and Sonneratia caseolaris. Meanwhile, Sungai Rembau-Linggi can be categorised as Rhizophora-Xylocarpus, and the mangrove forest at Sungai Chukai as Xylocarpus-Rhizophora. Based on the results, the increase in firefly populations of Pteroptyx tener could be due to the high population of $S$. cseolaris found in Sungai Sepetang. In addition, nipah palms (Nypa fruticans) and bebaru (Talipariti tiliaceum) also play important roles in conserving the habitat of fireflies.

The species diversity was highest at Sungai Chukai, followed by Sungai Rembau-Linggi and Sungai Sepetang. There were differences in the location that contributed to mangrove plant species composition, and the location of study sites (north to south of west coast and east coast Peninsular Malaysia) had low similarity percentage. The highest total estimation of AGB was at Sungai Rembau-Linggi. The lowest productive area was at Sungai Chukai although it had a higher number of individuals than other study sites.

In general, the values of biomass estimated were within the normal range of mangrove forest. In ecology studies, estimation of biomass is an important component in assessing the status of forest productivity. Furthermore, degradation and destruction of the mangroves can damage these riverine mangroves and impact the communities economically. These rivers also provide an ecosystem for firefly habitat that can generate income for the local people. The findings of this study may 
Table 6 Total estimation AGB of mangrove trees at three rivers in Peninsular Malaysia

\begin{tabular}{llccc}
\hline \multirow{2}{*}{ Family } & Species & \multicolumn{3}{c}{ AGB (tonnne ha-1) } \\
\cline { 3 - 4 } Avicenniaceae & Avicennia alba & Sungai Rembau-Linggi & Sungai Sepetang & Sungai Chukai \\
& Avicennia marina & 0.004 & - & 2.49 \\
& Avicennia officinalis & 0.006 & - & 2.71 \\
& Avicenna rhumpiana & 2.33 & - & 0.79 \\
Lythraceae & Sonneratia alba & - & - & 2.51 \\
& Sonneratia caseolaris & 28.27 & - & - \\
Reliaceae & Xylocarpus granatum & 10.81 & 24.04 & 0.37 \\
& Bruguiera cylindrica & 22.70 & - & 50.03 \\
& Bruguiera gymnorhiza & - & 0.25 & 1.03 \\
& Bruguiera parviflora & 6.21 & 3.51 & 0.93 \\
& Bruguiera sexangula & 6.75 & - & 2.38 \\
& Ceriops tagal & - & - & 2.26 \\
& Kandelia candel & - & - & 4.62 \\
& Rhizophora apiculata & - & 136.80 & 28.54 \\
& Rhizophora mucronata & 138.06 & 4.21 & 4.42 \\
\hline
\end{tabular}

be used as a primary source of information, and to provide baseline data for assessing the environmental parameters of riverine mangrove ecosystem in the region.

\section{ACKNOWLEDGEMENTS}

This study was facilitated by the Universiti Kebangsaam Malaysia's research grant (ST 2017-013), funded by Tenaga Nasional Berhad Research (TNBR). The authors would like to thank Emeritus Prof. Dato' Dr. Abdul Latiff Mohamad for his useful comments. The authors would also like to thank the various contributors such as Kemaman Mini Zoo, science officers, villagers and field assistants who shared their knowledge and assisted in data collection and analysis.

\section{REFERENCES}

Aldrie AA \& Latiff A. 2006. Hutan Simpan Merbok, Kedah: Warisan Kepelbagaian Hutan Paya Bakau. Jabatan Perhutanan Semenanjung Malaysia, Kuala Lumpur.

ALDRIE AA. 2018. Mitigate risk for Malaysia's mangroves. Science 359: 1342-1343.

Awang NA, Jusoh WH \& Hamid MRA. 2014. Coastal erosion at Tanjong Piai, Johor, Malaysia. Journal of Coastal Research 71: 122-130.
Brower JE, Zar JH \& Von Ende CN. 1998. Field and Laboratory Methods for General Ecology. $4^{\text {th }}$ Edition. Wm. C. Brown Publishers, Lowa.

Chно A \& Jost L. 2012. Coverage-based rarefaction and extrapolation: standardizing samples by completeness rather than size. Ecology 93: 2533-2547.

CHONG VC. 2006. Sustainable utilization and management of Mangrove ecosystems of Malaysia. Aquatic Ecosystem Health $\mathcal{E}$ Management 9: 249-260.

Curtis JT \& Macintosh RP. 1951. An upland continuum in the prairie-forest border region of Wisconsin. Ecology 32: 476-496.

DENSLOW JS. 1995. Disturbance and diversity in tropical rain forests: the density effect. Ecological Applications 5: 962-968. https://doi.org/10.2307/2269347.

Duke NC, Meynecke J-O, Dittmann S et al. 2007. A world without mangroves? Science 317: 41-42.

Faridah-Hanum I, Kamziah AK \& Nurul-Shida S. 2012. Plant diversity and biomass of marudu bay mangroves in Malaysia. Pakistan Journal of Botany 44: 151-156.

GAN SH. 2006. Flora dan Biojisim Pokok di Hutan Paya Bakau Mukim Pasir Panjang, Port Dickson dan Tanjung Tuan, Melaka. Universiti Kebangsaan Malaysia, Serdang.

Gbif (The Global Biodiversity Information Facility). 2020. The Global Biodiversity Information Facility (GBIF). https://www.gbif.org.

Giesen W, Wul FF, RaAt S, Zieren M \& Scholten L. 2007. Mangrove Guidebook for Southeast Asia. FAO and Wetlands International, FAO Regional Ofice for Asia and the Pacific, Bangkok.

Giri C, Ochieng E, Tieszen LL et AL. 2011. Status and distribution of mangrove forests of the world 
using Earth Observation Satellite Data. Global Ecology and Biogeography 20: 154-159.

Gotelli NJ \& Colwell RK. 2001. Quantifying biodiversity: procedure and pitfalls in the measurement and comparison of species richness. Ecology Letters. 4: 379-391. https://doi.org/10.1046/j.14610248.2001.00230.x.

Hamdan O, Muhamad Afizzul M \& Valeria L. 2018. Characterizing and monitoring of mangroves in Malaysia using Landsat-based spatial-spectral variability. IOP Conference Series: Earth and Environmental Science 169: 12-37.

Hammer. 2012. PAST (Paleontological Statistic) ver. 2.17c. References Manual. National Historical Museum, University of Oslo, Oslo.

Hamilton SE \& CASEy D. 2016. Creation of a high spatio-temporal resolution global database of continuous mangrove forest cover for the 21st century (CGMFC-21). Global Ecology and Biogeography 25: 729-738.

Hemati Z, Hossain M \& RoZAINAH MZ. 2014. Biodiversity and biomass of a natural and degraded mangrove forest of Peninsular Malaysia. Environmental Earth Sciences 71: 4629-4635. Doi:10.1007/s12665-013-2853-6.

Hitimana J, KiytaPi JL \& NJUNGE JT. 2004. Forest structure characteristics in disturbed and undisturbed sites of Mt. Elgon Moist Lower Montane Forest, Western Kenya. Forest Ecology and Management, 194: 269-291.

JusOH WFAW \& Hashim NR. 2012. The effect of habitat modification on firefly populations at the Rembau-Linggi River, Peninsular Malaysia. Lampyrid 2: 149-155.

Jusoh WFAW, Hashim NR \& Ibrahim ZZ. 2010a. Distribution and abundance of Pteroptyx fireflies in Rembau Linggi River, Peninsular Malaysia. Environment Asia 2: 56-60.

Jusoh WFAW, HaShim NR \& IBrahim ZZ. 2010b. Firefly distribution and abundance on mangrove vegetation assemblages in Sepetang River, Malaysia. Wetlands Ecology and Management 18: 367-373.

Jusoff K. 2013. Malaysian mangrove forest and their significance to the coastal marine environment. Polish Journal Environmental Studies 22: 979-1005.

KathiRESAN K. 2004. Ecology And Environment of Mangrove Ecosystem. UNU-INWEH-UNESCO International Training Course on Coastal Biodiversity in Mangrove Ecosystem Course Manual. Annamalai University, Tamil Nadu.

Kato R, Tadayaki Y \& Ogawa H. 1978. Plant biomass and growth increment studies in Pasoh forest. Malayan Nature Journal 30: 211-224.

Komiyama A, Poungparn S \& Kato S. 2005. Common allometric equations for estimating the tree weight of mangroves. Journal of Tropical Ecology 21: 471-477.

Magurran AE. 2004. Measuring Biological Diversity. Blackwell Publishing, United Kingdom

MPK (Majlis Perbandaran Kemaman). 2019. Laporan EIA Projek Pembangunan Lembangan Bersepadu
Sungai Kemaman. Majlis Perbandaran Kemaman, Kemaman.

Nada B, Kirton LG, Norma-Rashid Y, Cheng S, Shahlinney L \& PHON CK. 2012. Monitoring the freflies of the Selangor River. Pp 153-162 in Sasekumar A \& Chong VC (eds) Mangrove and Coastal Environment of Selangor, Malaysia, Institute of Ocean and Earth Sciences Monograph Series 14. University of Malaya, Kuala lumpur.

NG FSP. 1978. Tree Flora of Malaya. Volume 3. Longman Malaysia, Kuala Lumpur.

NG FSP. 1989. Tree Flora of Malaya. Volume 4. Longman Malaysia, Petaling Jaya.

Ohba N \& Wong CH. 2004. External morphology and ecological study of the firefly, Pteroptyx tener, at Kampung Kuantan, Selangor, Malaysia. Science Report of Yokosuka City Museum 51: 1-33.

Polidoro BA, Carpenter KE, Collins L et al. 2010. The loss of species: Mangrove extinction risk and geographic areas of global concern. PLOS One 5: $1-10$.

Poorter L, Bongers F, Rompaey RSAR \& Klerk MD. 1996. Regeneration of canopy tree species at five sites in West African moist forest. Forest Ecology Management 84: 61-69.

Putz FE \& Chan HT. 1986. Tree growth dynamics. Forest Ecology and Management 178: 211-230.

RichARDS DR \& FRIESS DA. 2016. Rates and rivers of mangrove deforestation in Southeast Asia, 20002012. Proceedings of the National Academy of Sciences 113: 344-349.

Spalding M, Blasco F \& Field C. 1997. World mangrove atlas. Okinawa Japan International Society for Mangrove Ecosystems, Okinawa.

Spellerberg IF \& Fedor PJ. 2003. A tribute to Claude Shannon (1916-2001) and a plea for more rigorous use of species richness, species diversity and the 'Shannon-Wiener' Index. Global Ecology $\mathcal{E}$ Biogeography 12: 177-179.

Wan-Juliana WA, Md.-Shahril MH, Nik-Abdul-Rahman NA, Nurhanim MN, Maimon A \& Norela S. 2012. Vegetation profile of the firefly habitat along the riparian zones of Sungai Selangor at Kampung Kuantan, Kuala Selangor. Malaysian Applied Biology 41: 55-58.

Wan-Juliana WA, Muhammad-Razali S \& Latiff A. 2014. Mangrove Ecosystems of Asia: Status, Challenges and Management Strategies. Chapter 2. Distribution and Rarity of Rhizophoraceae in Peninsular Malaysia. Springer, New York.

Wan-Norilani WI, Wan-Juliana WA, Muhammad-Razali S \& LATIFF A. 2018. Structural and floristic pattern in a disturbed mangrove tropical swamp forest: a case study from the Langkawi UNESCO Global Geopark Forest, Peninsular Malaysia. Sains Malaysiana 47: 861-869.

Whitmore TC. 1972. Tree Flora of Malaya. Volume 1. Longman Malaysia, Kuala Lumpur.

Whitmore TC. 1973. Tree Flora of Malaya. Volume 2. Longman Malaysia, Kuala Lumpur. 